\title{
Індивідуально-психологічні властивості та прагнення до професійного самовдосконалення як внутрішні чинники професійного розвитку
}

\begin{abstract}
Анотація. У статті представлено результати емпіричного дослідження таких внутрішніх чинників професійного розвитку практичного психолога, як професійно значущі індивідуально-психологічні властивості та прагнення до професійного самовдосконалення. Це прагнення розглянуто як мотиваційно-иільове утворення, як иіль забезпечуючої діяльності самовдосконалення. Проаналізовано індивідуально-психологічні властивості практичних психологів, які перебувають на різних етапах професіогенезу. Виявлено особливості і тендениії реальної професійної поведінки практичних психологів. Знайдено зв'язки факторів особистості (за Р. Кеттеллом) з прагненням до самовдосконалення. Визначено, щьо професійно значущі індивідуально-психологічні властивості та комунікативні установки є особистісною основою прагнення до професійного самовдосконалення.

Ключові слова: професійний розвиток, етапи професіогенезу, прагнення до професійного самовдосконалення, професійна успішність, професійний досвід, індивідуальний стиль професійної діяльності, комунікативна поведінка.
\end{abstract}

Постановка проблеми. Дослідження внутрішніх чинників професійного становлення, зокрема, індивідуально-психологічних властивостей практичних психологів, спрямоване на виявлення закономірностей та механізмів професійного розвитку. Професійно значущі індивідуально-психологічні властивості є і особистісною основою прагнення до професійного самовдосконалення, яке ми розглядаємо як мотиваційноцільове утворення, як ціль забезпечуючої діяльності самовдосконалення.

Аналіз останніх досліджень 3 проблеми. Аналіз психологічних досліджень, в яких вивчалися внутрішні чинники професійного розвитку, зокрема, професійно значущі індивідуально-психологічні властивості, показав, що більшість науковців дотримуються думки про те, що професійний розвиток практичного психолога не може бути зведений до проблеми формування професійно важливих якостей. Але все ж-таки їх роль залишається важливою і вони є певним орієнтиром для самовдосконалення. Звернімо увагу на те, що інтегральні професійно і соціально значущі констеляції різноманітних якостей та вмінь утворюються у процесі активного засвоєння професійної діяльності і прояв- ляються в індивідуальному стилі діяльності $[5 ; 4 ; 1]$.

Постійні і швидкі зміни у сучасному житті вимагають неперервної підготовки й перепідготовки фахівців, неперервного навчання й постійної модернізації вмінь, а отже, і відповідних змін у характері професійних компетенцій. Тому сучасні психологи вважають, що професійний розвиток на різних етапах професіоналізації не може відбуватися без саморозвитку, самовдосконалення особистості [2; 3; 4]. Як свідчить теоретичний аналіз, багатогранна i складна проблема самовдосконалення потребує нових концептуальних підходів і специфічних методичних засобів (Л.І. Анциферова, О.Г. Асмолов, Є.Є. Вахромов, Д.О. Леонтьєв, А. Маслоу, К. Роджерс, Т.М. Титаренко).

В даній роботі представляються результати дослідження таких внутрішніх чинників професійного розвитку практичного психолога, як професійно значущі індивідуально-психологічні властивості та прагнення до професійного самовдосконалення. Завдання емпіричного дослідження: 1) дослідити індивідуально-психологічні властивості практичних психологів, які перебувають на різних етапах професіо- 
генезу; 2) оцінити практичних психологів за визначеними професійно значущими індивідуально-психологічними властивостями; 3) виявити особливості і тенденції реальної професійної поведінки практичних психологів (зокрема, наявність/відсутність прагнення до самовдосконалення); 4) оцінити успішність професійної діяльності практичних психологів; 5) знайти зв'язок факторів особистості (за Р. Кеттеллом) 3 експертними оцінками наявності/відсутності прагнення до самовдосконалення у досліджуваних.

Виклад основного матеріалу дослідження. Реалізація перелічених завдань відбувалася за допомогою опитувальника 16 PF Р. Кеттелла та через оцінювання експертами за допомогою авторської методики «Експертна оцінка співробітника» індивідуально-психологічних властивостей практичних психологів і успішності їх професійної діяльності. У подальшому ці оцінки були співвіднесені з результатами, отриманими за допомогою опитувальника Р. Кеттелла 16 PF-187-А і методики вивчення комунікативних установок особистості (О. І. Іванова, О.В. Заїки, стандартизація Н. А. Бельської і М. А. Міропольської) [6].

Зауважимо, що проведений нами аналіз теоретичних джерел щодо вивчення різних аспектів професійного розвитку та емпіричних досліджень цього процесу, а також власне пілотажне дослідження, показали, що саме ці методики є достатньо ефективними для виявлення професіонально значущих індивідуально-психологічних властивостей, особливостей реальної професійної діяльності, вимог професії до практичного психолога.

Розглянемо опитувальник Р. Кеттелла 16 PF-187-А. Не дивлячись на існування скорочених варіантів цього діагностичного інструменту (зокрема, В-5), ця версія опитувальника видається нам більш гнучким i змістовним методом дослідження особистості. Методика вивчення комунікативних установок на практиці показала свою високу прогностичну спроможність в діагностиці комунікативних позицій особистості - суттєвого фактора успішності профе- сійної діяльності практичного психолога [6]. Авторська методика «Експертна оцінка співробітника» дозволяє виявити певні особливості і тенденції реальної професійної поведінки i, зокрема, наявність/відсутність прагнення до самовдосконалення.

Первинне структурування груп досліджуваних відбувалося відповідно етапів професійного становлення особистості (Е.Ф. Зеєр, С.О. Клімов, Е.Е. Симанюк), які співпадають 3 формальною ознакою «стаж роботи за спеціальністю»: 1) професійна адаптація, а саме входження у професію, засвоєння професійних технологій, набуття досвіду самостійного виконання професійної діяльності; зазвичай цей етап (фаза адаптанта) триває від 1 до 3 років професійної діяльності, тому досліджувані $з$ таким стажем входили до 1-ої групи; 2) первинна і вторинна професіоналізація (формування професійної свідомості; інтеграція професійно і соціально важливих якостей і вмінь у відносно стійкі професійно значущі констеляції; високоякісне виконання професійної діяльності) — як правило, цей етап (фаза інтернала) триває від 3 до 8 років професійної діяльності, тому досліджувані з таким стажем входили в 2-гу групу; 3) професійна майстерність (більш-менш повна реалізація, самоздійснення особистості у професійній діяльності на основі рухомих інтегративних психологічних новоутворень професійного розвитку, зокрема «акме») - як правило, цей етап (фаза майстерності) настає після 8 років професійної діяльності, тому досліджувані $з$ таким стажем входили в 3-ю групу.

В дослідженні прийняло участь 180 практичних психологів, що належали до вище названих груп (1 група — «адаптанти»; 2 група - «інтернали»; 3 група «майстри»), по 60 практичних психологів у кожній групі.

Як було сказано вище, для оцінки реальної професійної поведінки практичних психологів було застосовано метод експертних оцінок. В експертному опитуванні брали участь 32 експерти: методисти і колеги по роботі (серед яких були провідні фахівці в області практичної психології) із профе- 
сійним психологічним досвідом не менше 5 років. Кожний експерт добре знав (як свого колегу по професійній психологічній діяльності) того практичного психолога, якості якого він оцінював. Кожного досліджуваного оцінювали 3 експерти.

Серед оцінюваних властивостей важливе місце займало прагнення до самовдосконалення, яке ми розглядаємо як мотиваційно-цільове утворення, як ціль забезпечуючої діяльності самовдосконалення. Наявність прагнення до самовдосконалення ззовні виявляється за параметрами, викладеними вище.

Емпіричні дані, отримані за допомогою опитувальника Р. Кеттелла, методики вивчення комунікативних установок особистості і методики експертних оцінок, дають можливість зіставити індивідуально-психологічні властивості, комунікативні установки, професійну успішність, прагнення до самовдосконалення, що притаманні практичним психологам, які перебувають на різних етапах професіогенезу. Таким чином ми можемо визначити особистісні основи прагнення до самовдосконалення i отримати об'єктивну картину динаміки змін індивідуально-психологічних властивостей, пов'язану, зокрема, з професійним досвідом. Крім того, це дозволяє виділити ті індивідуально-психологічні властивості практичних психологів, які тією чи іншою мірою властиві досліджуваним із різних груп (структурованих за певними етапами професіогенезу), і скласти «психологічні портрети» цих груп.

Інтерпретація отриманих матеріалів відбувалася в логіці пошуку психологічних механізмів професійного розвитку практичних психологів.

Розглянемо основні результати емпіричного дослідження.

На основі кластерного аналізу в усіх досліджуваних групах виокремлено по дві підгрупи з біполярними тенденціями: практичні психологи, у яких існує прагнення до професійного самовдосконалення, i ті, у яких це прагнення відсутнє. Наявність прагнення до самовдосконалення зафіксовано у $30 \%$ досліджуваних 1-ої групи, у 70\% - 2-ої групи і $65 \%$ - 3-ої групи. Відсутність прагнення до самовдосконалення виявлено у $70 \%$ досліджуваних 1-ої групи, у $30 \%$ - 2-ої групи і $35 \%$ - 3-ої групи.

За допомогою кореляційного аналізу Пірсона було виявлено певні зв'язки між параметром «прагнення до самовдосконалення» (який отримано на основі експертних оцінок) та шістнадцятьма особистісними факторами, числове вираження яких було визначене за допомогою методики $16 \mathrm{PF}$ Кеттелла. Нагадаємо, що в опитувальнику Кеттелла кожний фактор відображує тільки одну із суттєвих особистісних властивостей, які включають якості, що ії складають. Звідси витікає, що виокремлені властивості $\epsilon$ незалежними від інших і не корелюють 3 ними. Фактори включають полярні характеристики властивості, a їх інтерпретація визначається кількістю стенів. Тобто, кожна властивість представлена в опитувальнику в континуумі його крайніх проявів.

Отже, знайдено значущі зв'язки між параметром «прагнення до самовдосконалення» та сімома особистісними факторами методики 16 PF Р. Кеттелла.

Наявність прямого зв'язку між прагненням до самовдосконалення та фактором $\mathrm{F}$ (стриманість-експресивність) (0,336 при $\mathrm{p}=0,001)$ свідчить про те, що людям, у яких існує це прагнення, притаманні: оптимізм, життєрадісність, енергійність, відвертість. Для таких людей соціальні контакти $є$ високо значущими, що має безсумнівно важливе значення для психолога-професіонала. Також для представників нашої вибірки, у яких є прагнення до вдосконалення, характерна щирість у стосунках і емоційність.

Наявність прагнення до самовдосконалення свідчить ще і про соціальну сміливість, активність, чутливість, доброзичливість, емоційність, навіть деяку безстрашність та безтурботність. Про це говорить наявність прямого зв'язку між цим показником та фактором $\mathrm{H}(0,299$ при $\mathrm{p}=0,05)$.

Наступний зв'язок, на який ми звернемо увагу, це зв'язок прагнення до вдоско- 
налення себе та фактору J (ніжність-суворість, жорстокість). Зв'язок зворотній, що вказує на те, що наявність прагнення до самовдосконалення свідчить про реалістичність і практичність досліджуваних осіб, впевненість у собі, готовність брати на себе відповідальність за результати власних вчинків чи відсутність страху відповідальності (-0,334 при р =0,001).

Наступний зв'язок (між параметром та фактором L $(-0,436$ при $p=0,001)$ вказує, що досліджувані, які проявляють прагнення до самовдосконалення, мають низький рівень підозрілості, є вільними від залежностей, стереотипів, пересторог, розуміють і пробачають інших, доброзичливі, легко знаходять спільну мову з людьми, тобто їм легко працювати у колективі.

3 другого боку, прагнення до самовдосконалення говорить про високий творчій потенціал людини, іiі багату уяву, деяку богемність і розсіяність - фактор $\mathrm{M}(0,333$ при $\mathrm{p}=0,001)$. Для таких досліджуваних притаманна цікавість до мистецтва і різноманітних теорій.

Прагнення до вдосконалення себе допомагає людині «проробити» імовірні почуття провини, депресії, оскільки для них характерними $є$ оптимізм, життєрадісність, щаслива вдача $\mathrm{O}(-0,381$ при $\mathrm{p}=0,001)$. Також цим досліджуваним властива самодостатність, критичне відношення до оцінок оточуючих.

Наявність прямого зв'язку між прагненням до самовдосконалення та фактором Q3 $(0,413$ при $\mathrm{p}=0,001)$ свідчить про те, що люди, у яких існує це прагнення, відрізняються точністю, вольовими якостями, високим самоконтролем, можуть ефективно впливати на інших і бути успішними лідерами, діють за узгодженим планом, приймають соціальні норми та контролюють свої емоції та поведінку.

Тепер перейдемо до аналізу результатів емпіричного дослідження індивідуальнопсихологічних властивостей практичних психологів, які перебувають на різних етапах професіогенезу. Цей матеріал ми будемо викладати в логіці порівняння різних груп досліджуваних. Перш за все, зверні- мо увагу на ті показники, за якими не виявлено відмінностей між групами. Показники представників 1-ої групи («адаптанти») майже не відрізняються від показників представників 2-ої групи («інтернали») за шкалами, які представлені разом із показниками середнього по групах.

Спочатку звернімо увагу на числові показники фактору А (комунікабельність). Так, за результатами проведеного дослідження встановлено, що статистично значимої різниці між показниками обох груп (1 і 2) не виявлено. Середньогрупові значення демонструють, що представники обох груп достатньо комунікабельні, відкриті, природні, готові до співробітництва, уважні до людей, проявляють готовність до спільної роботи, легкість у встановлені безпосередніх міжособистісних контактів.

У представників обох груп на однаковому (середньому рівні) представлені сміливість у спілкуванні, вміння легко вступати в контакт 3 незнайомими людьми, теплота і відкритість у спілкуванні, вміння слухати, вміння бути уважним; вміння знаходити спільну мову 3 різними людьми, здібність викликати довіру, тактовність, дипломатичність, вміння встановлювати позитивні контакти з людьми; впевненість у собі; вміння впливати на інших, вміння мотивувати людей до роботи над своїми проблемами; вміння швидко знаходити індивідуальний підхід до людей залежно від їх особливостей; вміння переконувати людей, залагоджувати незгоди.

Зауважимо, що у своїх оцінках рівня професійної успішності досліджуваних (а саме: знання психології людей; професійні знання; відповідність вмінь і навичок професійним задачам, які доводиться вирішувати; вміння у встановлений строк, без помилок виконувати більшість професійних завдань і доводити їх до кінця; наявність достатнього професійного досвіду; вміння вирішувати складні завдання; висока відповідальність і самоконтроль; володіння широким спектром професійних навичок і вмінь) експерти побачили різку поляризацію всередині 2-ої групи: частина практичних психологів отримала досить 
високі оцінки (7,5 балів) свого професіоналізму (вони досить швидко вирішують професійні завдання, терпляче ставляться до типових професійних труднощів), а частина - низькі (4,6 бали).

Групи 1-а («адаптанти») та 3-я («майстри») майже не відрізняються між собою. Варто зазначити, що згідно встановлених показників, найменше «схожості» в оцінках виявлено якраз щодо цих груп.

Згідно 3 отриманими результатами, для представників обох групп (1-a - «адаптанти» та 3-я — «майстри») характерною $\epsilon$ самовпевненість, незалежність у думках, самостійність, самодостатність. Для представників 1-ої групи характерним $є$ невизнання авторитетів.

Оскільки респонденти - представники трьох різних за досвідом груп - можна припустити, що по мірі накопичення професійного досвіду, спеціалісти починають вибудовувати власну систему роботи, власний індивідуальний стиль, можливо, власну «наукову парадигму», що дозволяе їм проявляти самовпевненість, самоповагу самодостатність. Для «адаптантів» (молодих спеціалістів) високий рівень прояву риси «невизнання авторитетів» є своєрідним захисним механізмом, який, по-перше, дозволяє сміливіше робити перші кроки на шляху професійного становлення, подруге, дозволяє не втрачати критичність до різних напрямів та парадигм професійної діяльності.

Порівняльний аналіз індивідуальнопсихологічних властивостей досліджуваних трьох груп показує, що «психологічні портрети» 2-ої та 3-ої груп доволі схожі. Зокрема, показники представників 3-ої групи майже не відрізняються від показників представників 2-ої за цілим рядом шкал, які представлені разом із показниками середнього по групах. Варто зазначити, що між оцінками даних груп встановлена найбільша схожість. Це може свідчити, що саме ці особистісні та професійно важливі риси відшліфовуються по мірі професійного становлення.

Згідно 3 отриманими результатами, для представників обох груп характерною є самовпевненість, незалежність у думках, прагнення керуватись власними правилами поведінки, самодостатність.

Досить високі оцінки по фактору G (нормативність поведінки) вказують не тільки на досить високий рівень вираження вольових якостей респондентів, але й на схильність до співробітництва. Окрім того, ці результати описують досліджуваних як вимогливих до себе, відповідальних, схильних брати на себе відповідальність. Проте може проявлятися і неорганізованість, імпульсивність, незгода із загальноприйнятими нормами та стандартами поведінки, гнучкість стосовно даних норм та свобода від їх впливу.

Представників обох груп також об'єднує висока швидкість вирішення практичних завдань, орієнтація на зовнішню реальність, розвиток конкретної уяви, практична реалістичність. Результати нашого дослідження вказують, що для респондентів цих груп є властивим оптимізм, життєрадісність, упевненість у собі та своïx силах, спокій. Досліджувані достатньо консервативні, поважають принципи та терпеливо відносяться до традиційних (типових) труднощів, що можуть виникати в тому числі і у професійній діяльності.

Представники обох груп прислухаються до вимог та думки референтної групи, відрізняються високим рівнем соціабельності, прагнуть працювати та приймати рішення разом $з$ іншими людьми. Респондентам притаманний високий контроль емоцій i поведінки, цілеспрямованість, сильна воля. Також заслуговує на увагу незначний рівень фрустрованості і напруженості у спеціалістів обох груп.

Згідно результатів експертних оцінок, між представниками 2-ої і 3-ої груп відсутні статистично значимі відмінності у властивостях, які пов'язані з процесом обробки та осмислення соціальної інформації, зокрема: у соціальному мисленні, здатностях аналізувати поведінку оточуючих, розумітися на взаємовідносинах інших; у професійній рефлексії; у самоконтролі, самокритичності, самооцінці (які лежать в основі критичності мислення). Варто зазначити, 
що згідно результатів опитування, у представників обох груп вираженість даних якостей $є$ вищою за середні значення.

Також для представників 2-ої («інтернали») і 3-ої («майстри») груп притаманним $\epsilon$ високий самоконтроль (врівноваженість, тобто контроль емоцій і поведінки; стриманість; вміння адекватно поводити себе в різних складних обставинах; самовладання; витримка); високий рівень відповідальності, надійність (про таких людей говорять: «на нього можна покластися»); вимогливість до себе, організованість; енергійність, прагнення діяти, висока активність та працездатність; вміння наполегливо працювати; самостійність; емоційна стабільність.

Аналіз результатів тестування трьох груп за тестом 16 PF Р. Кеттелла показав, що «психологічний портрет» 1-ої групи («адаптанти») є найбільш відмінним від «психологічних портретів» двох інших груп (2-ої — «інтернали» і 3-ої — «майстри»). Зокрема, психологи-початківці $\epsilon$ більш залежними та несамостійними, їм простіше та безпечніше приймати рішення разом з іншими людьми, працювати, відчуваючи поряд опору. Відповідно, у молодих спеціалістів, в силу їх недостатньої професійної адаптованості, відмічається вищий рівень стурбованості, фрустрованості, напруженості. Молоді психологи є більш сміливими (зокрема, в спілкуванні), активними, схильними до ризику, ініціативнішими, ніж їхні старші колеги. Ці факти можна пояснити і віковими особливості молоді (вони більш схильні до ризику), і життєвою необхідністю завоювати своє місце під сонцем. Для молодих спеціалістів також більш властиве експериментаторство, висока чутливість до змін, нових ідей, недовіра до авторитетів.

«Психологічні портрети» 2-ої та 3-ої груп доволі схожі за факторами Е («домінантність-конформність»), G («підвладність почуттям - висока нормативність поведінки»), М («мрійливість-практичність»), О («схильність до почуття провини - самовпевненість»), Q1 («гнучкість-вигідність»), Q2 («конформізм-нонконформізм»), Q3 («контроль бажань — імпульсивність»),
Q4 («розслабленість-енергійність»). Це свідчить про те, що професійно значущі індивідуально-психологічні властивості, які відображено в цих факторах, «відшліфовуються» у процесі професійного становлення. Більш досвідчені фахівці (представники 2-ої - «інтернали» і 3-ої групи - «майстри») порівняно 3 психологами із 1-ої групи («адаптанти») є більш сильними, незалежними, реалістичними, схильними покладатись лише на власні сили.

Отримані результати виявили тенденції: зростання у практичних психологів (від фази адаптації до фаз інтернала і майстерності) вимогливості до себе, відповідальності, впевненості в собі, самодостатності, самостійності, цілеспрямованості; розвитку вольових якостей; покращення оцінок професійно важливих якостей спеціалістів із зростанням їх досвіду роботи.

Висновки. Показано, що досліджувані, які проявляють прагнення до самовдосконалення, відрізняються якостями, що свідчать про досить високій рівень розвитку: комунікативних якостей (соціальну сміливість, доброзичливість, вміння легко знаходити спільну мову 3 іншими людьми); вольової сфери (вміють контролювати свої емоції та поведінку, готові брати на себе відповідальність за результати власних вчинків, приймають соціальні норми).

Виявлено, що прагнення до вдосконалення себе допомагає людині «проробити» імовірні почуття провини, депресії, оскільки для них характерними $є$ оптимізм, життєрадісність, щаслива вдача.

Показано, що в середині групі досліджуваних, які мають професійний досвід більше трьох років (група — «інтернали») спостерігається різка поляризація: частина практичних психологів демонструють високий професіоналізм (вони досить швидко вирішують професійні завдання, терпляче ставляться до типових професійних труднощів, володіють широким спектром професійних навичок і вмінь тощо), а частина - низькій.

Відмічається високий рівень стурбованості, фрустрованості, напруженості у молодих спеціалістів (зокрема, в силу їх 
недостатньої професійної адаптованості). В той же час, молоді психологи є більш сміливими (зокрема, в спілкуванні), активними, схильними до ризику, ініціативнішими, ніж їхні старші колеги.

Більш досвідчені фахівці («інтернали» $\mathrm{i}$ «майстри») порівняно з молодими психологами («адаптантами») є більш сильними, незалежними, реалістичними, схильними покладатись лише на власні сили.
Виявлено тенденції: зростання у практичних психологів (від фази адаптації до фаз інтернала і майстерності) вимогливості до себе, відповідальності, впевненості в собі, самодостатності, самостійності, цілеспрямованості; розвитку вольових якостей; покращення оцінок професійно важливих якостей спеціалістів із зростанням їх досвіду роботи.

\section{Список використаних джерел:}

1. Анцыферова Л.И. Психологические закономерности развития личности взрослого человека и проблема непрерывного образования / Л.И. Анцыферова // Психологич. журнал. - 1980. - Т. 2. — №2. - С. 52-66.

2. Асмолов А.Г. Психология личности / Александр Григорьевич Асмолов. - М. : Изд-во МГУ, 1990. - $367 \mathrm{c}$.

3. Вахромов Е.Е. Вершины жизни и пути их достижения: самоактуализация, акме и жизненный путь человека / Евгений Евгеньевич Вахромов // Прикладная психология и психоанализ. - 2001. - № 4; 2002. — № 1, № 2 .

4. Зеер Э. Ф. Психология профессий : учебное пособие / Э. Ф. Зеер. - М. : Академический проект, 2005. - 336 с.

5. Маркова А.К. Психология профессионализма / А.К. Марковва. — М. : Гардарики, 1996. $-308 \mathrm{c}$.

6. Методи психодіагностики в системі професійної консультації безробітних : методичний посібник / [за ред. : В. В. Синявського, О. О. Ящишин]. — Київ, 2000. - 314 с.

Аннотация. В статье представлены результаты эмпирического исследования таких внутренних факторов профессионального развития практических психологов, как профессионально значимые индивидуально-психологические свойства и стремление к профессиональному самоусовершенствованию. Это стремление рассматривается как мотивационно-иелевое образование, как иель обеспечивающей деятельности самоусовершенствования. Проанализированы индивидуально-психологические свойства практических психологов, которые находятся на разных этапах професиогенеза. Выявлены особенности и тенденции реального поведения практических психологов и связи факторов личности (по Р. Кеттеллу) со стремлением к самоусовершенствованию. Определено, что профессионально значимые свойства и коммуникативные установки являются личностной основой стремления к профессиональному самоусовершенствованию.

Ключевые слова: профессиональное развитие, этапь професиогенеза, стремление к профессиональному самоусовершенствованию, профессиональная успешность, профессиональный опыт, индивидуальный стиль профессиональной деятельности, коммуникативное поведение.

Abstracts. Was showed the results of empirical investigation such internal factors of the professional development: professional significant individual-psychologist properties and the ambition to the professional self-development. This ambition is considering as a motivational-objective formation, as the aim of providing activity of self-improvement. Was analyzed the individual-psychological properties of practical psychologists which is locating on the different stages of the professiogenesis. The features and trends of real practical psychologists' professional behavior were founded. The connections between personality's factors (R. Kettel) and aspiration to the self-improvement were founded. Was showed that investigated which show the ambition to the self-development is distinguishing of the qualities which show the really high stage of development: the communicative qualities (social courage, goodwill, the skill to finding the common language with people); the qualities of volitional area (have control of emotions and behavior, ready to take the responsibility for results of own acts, accept the social norms). The tendency of: psychologists 'professional grown (from adaptation stage to the stage of internal and mastery), the demanding of themselves, responsibility, confidence, self-sufficiency, autonomy, commitment; the development of volitional qualities; the improvements of rating of professionally important qualities what support by growing of their experience were determined. Was grounded, that the professional important individual properties and the communicative installation is the personal base of aspiration to 
the self-improvement. Psychological technology of optimization of practical psychologist's professional development in the continuous education system are emphasized; experimentally tested psychological conditions of optimization of professional development are revealed.

Keywords: professional development, stages of professiogenesis, aspiration to the self-improvement, professional success, professional experience, individual style of professional activity, communicative behavior. 